\title{
IMMUNIZATION OF RABBITS AGAINST FSH AND EFFECTS ON THE ZONA PELLUCIDA
}

\author{
R. MONASTIRSKY, ELSA B. SCHUCHNER* AND R. B. DEU \\ Centro de Investigaciones en Reproducción, \\ Facultad de Medicina, Buenos Aires, Argentina
}

(Received 8th Fanuary 1974)

\begin{abstract}
Summary. The effects of active FSH immunization on the ovarian morphology of adult rabbits were studied. Rabbits were immunized intradermally in multiple sites with antibodies to ovine FSH. Both the macroscopic morphology and the weight of the ovaries of the experimental rabbits were similar to those of the controls. Multiple branched projections of the granulosa cells were seen in the experimental rabbits. These projections had higher electron density than the rest of the cell. The zona pellucida was not formed although the growing follicles were large enough to have a completely formed layer. Disturbance of the metabolism of the follicular cells, due to the lack of endogenous FSH, could explain this abnormality.
\end{abstract}

Experiments concerning the rôle of FSH in oogenesis and ovulation have been mainly limited to evaluation of the effects of FSH injections into immature and/or hypophysectomized animals (Casida, Meyer, McShan \& Wisnicky, 1943; Simpson \& van Wagenen, 1953; Greep, 1961). Recently, it has been demonstrated that foreign gonadotrophins are antigenic in the rabbit (Segal, Laurence, Perlbachs \& Hakim, 1962; Talaat \& Laurence, 1969; Schwartz \& Ely, 1970; Monastirsky, Laurence \& Tovar, 1971; Schuchner \& Monastirsky, 1973). The aim of this study was to describe the effects of active anti-FSH immunization on the ovarian morphology of adult rabbits and the possible mechanism of action of FSH.

Ten adult white New Zealand rabbits of approximately $3 \mathrm{~kg}$ body weight were immunized intradermally in multiple nuchal sites with $5.0 \mathrm{mg}$ ovine FSH (NIH-FSH-S8) dissolved in $1.0 \mathrm{ml}$ saline and then emulsified with an equal volume of Freund's complete adjuvant (Difco). Two additional injections were administered at 1-week intervals using $2.0 \mathrm{mg}$ FSH in Freund's adjuvant per rabbit.

Six rabbits were used as controls for the experiment; three were injected with saline and three with Freund's complete adjuvant alone.

Antisera were characterized by microhaemagglutination (Boyden, 1951) and double agar gel diffusion against FSH (NIH-FSH-S8), LH (NIH-LH-B7), STH (NIH-STH-S9), TSH (NIH-TSH-S6) and LtH (NIH-LtH-S6). For

\footnotetext{
* Reprint requests to: Dr Elsa B. Schuchner, C.I.R., Facultad de Medicina, Paraguay 2155-10 piso, Buenos Aires, Argentina.
} 
microhaemagglutination procedures, formolized and tanned sheep red blood cells were modified with ovine FSH (NIH-FSH-S8) at a concentration of $0.02 \mathrm{mg} / \mathrm{ml}$; with bovine LH (NIH-LH-B7), $0.02 \mathrm{mg} / \mathrm{ml}$; with ovine TSH (NIH-TSH-S6), $0.02 \mathrm{mg} / \mathrm{ml}$; with ovine STH (NIH-STH-S9), $0.04 \mathrm{mg} / \mathrm{ml}$ and with ovine LtH (NIH-LtH-S6), 0.02 to $0.10 \mathrm{mg} / \mathrm{ml}$.

For double agar gel diffusion, the concentration of agar (Bacto Agar, Difco) was $1.5 \%$ in phosphate buffer, $\mathrm{pH} 7 \cdot 2$. The centre wells were charged with undiluted anti-FSH serum and the five satellite wells with $1 \mathrm{mg} / \mathrm{ml}$ of FSH, $\mathrm{LH}, \mathrm{TSH}, \mathrm{STH}$ and $\mathrm{LtH}$ respectively.

For light microscope observations, ovaries were fixed in buffered formaldehyde and processed in a Tissuemat. Sections were stained with haematoxylin and eosin and periodic acid-Schiff (PAS).

For electron microscopy, ovaries were fixed in $2.5 \%$ glutaraldehyde at $4^{\circ} \mathrm{C}$ for $3 \mathrm{hr}$, washed twice in phosphate buffer, $\mathrm{pH} 7 \cdot 2$, and postfixed in Caufield's solution for $2 \mathrm{hr}$ at $4^{\circ} \mathrm{C}$. After dehydration, the tissue was embedded in Maraglas epoxy resin. Sections were cut on a Porter Blum ultramicrotome and were stained with uranyl acetate and lead citrate. Grids were examined with a Siemens Elmiskop I.

The titre of anti-FSH, checked by microhaemagglutination, was between $1 / 1280$ and $1 / 2560$. The main contaminant was anti-TSH at a titre between $1 / 640$ and $1 / 2560$. The anti-LH titre was between $1 / 160$ and $1 / 320$; no titre against $\mathrm{LtH}$ and $\mathrm{STH}$ was detected.

The double agar gel diffusion showed three bands against FSH, two of which had identity against $\mathrm{LH}$, three or four bands (depending on the serum tested)) against TSH, one of which showed identity against FSH and LH, one or two bands against STH and no band against LtH.

No differences were noted in the macroscopic morphology of the ovaries of control animals treated either with saline or Freund's complete adjuvant alone. The weight of the ovaries of the experimental does were similar to those of the controls (approximately $250 \mathrm{mg}$ ). The ovaries of the control and experimental does contained numerous primordial follicles. Growing follicles in the control does were formed by four to eight follicular layers surrounding the oocyte, and cavitation was present in follicles that had six or more layers. By contrast, growing follicles from the experimental does had only two layers of cells but showed cavitation. Though the size of these structures was approximately half that of the control follicles, the size of the cells was similar. No ripe follicles were seen in the immunized rabbits. The granulosa cells of the 'growing' follicles in the experimental animals had a denser cytoplasmic matrix, with normal and

\section{EXPLANATION OF PLATE 1}

Frg. 1. Section of a primordial folicle of rabbit treated with anti-FSH serum. The arrow shows the projections of the follicular cells. ff, Follicular fluid; bm, basal membrane; 0 , oocyte. $\times 2960$.

FIG. 2. A higher magnification of one of the cytoplasmic projections shown in Fig. 1. The arrow indicates the cellular junctions between the projections. fc, Follicular cells. $\times 8890$.

Frg. 3. A growing follicle of a rabbit treated with anti-FSH serum. Straight arrow indicates the follicular projections surrounding the oocyte. Curved arrow shows follicular projections in abnormal areas. o, Oocyte; fc, follicular cell; ff, follicular fluid; bm, basal membrane. $\times 2960$. 

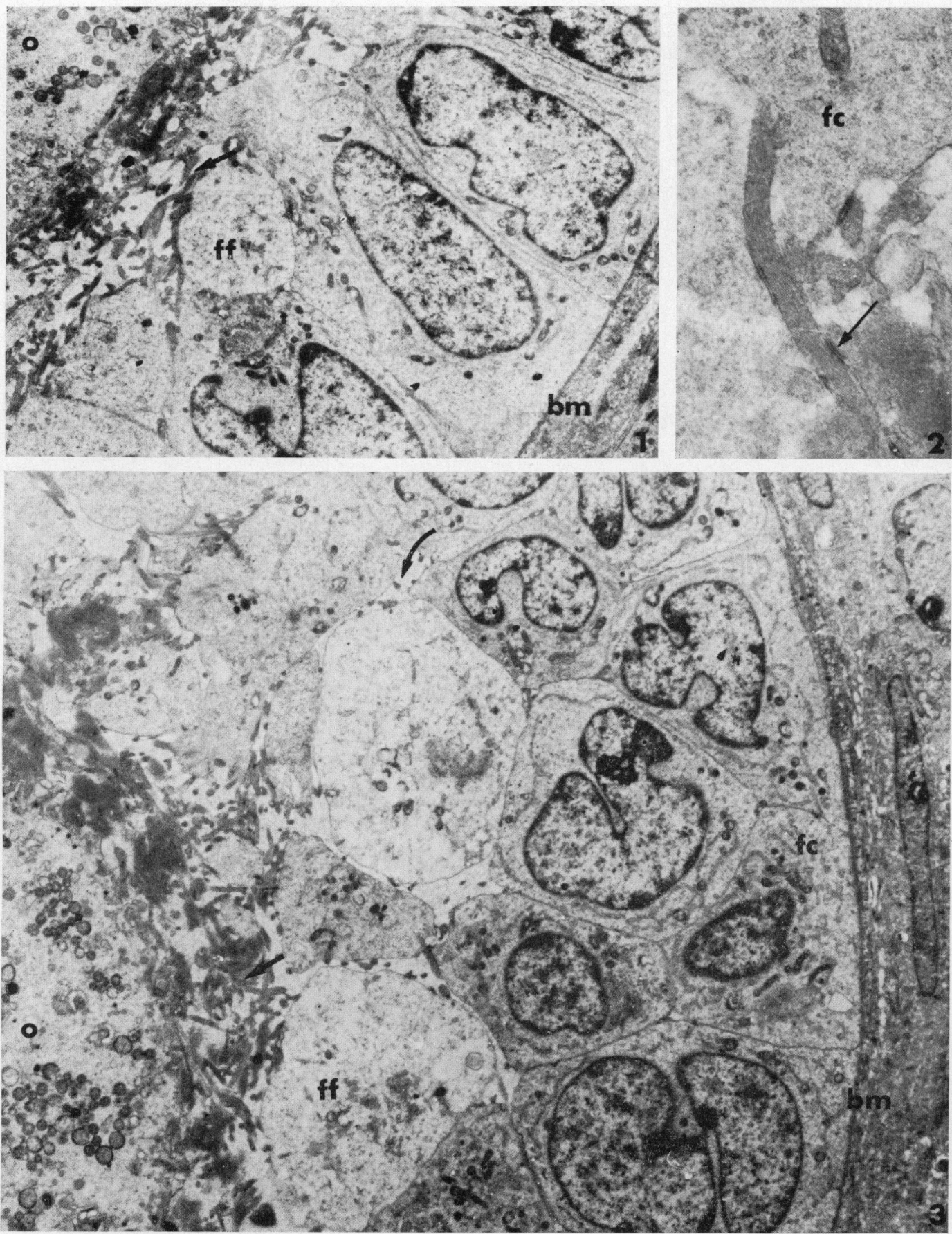
well-preserved organelles. Most of the follicular cells had multiple branched projections (Pl. 1, Figs 1 to 3 ). These cytoplasmic projections were seen not only in the areas close to the oocyte but were observed surrounding the cell in direct contact with follicular fluid. The cytoplasm of the projections had higher electron density than the rest of the cell because of a condensation of microfilaments (Pl. 1, Fig. 2). The area where the zona pellucida is usually expected to be was crowded with multibranched projections. Processes were closely attached by junctions of intermediate type (Pl. 1, Fig. 2). The oocytes of the growing follicles were well-preserved and their microvilli were contiguous with the projections of the granulosa cells. The cytoplasmic projections were consistently PAS-negative.

Neutralization of endogenous pituitary gonadotrophins by antibodies has been demonstrated previously by several authors (Segal et al., 1962; Talaat \& Laurence, 1969; Schwartz \& Ely, 1970; Monastirsky et al., 1971; Schuchner \& Monastirsky, 1973). Talaat \& Laurence (1969) showed that active FSH immunization in rabbits diminished their fertility. In our laboratories, histological studies of the pituitary of rabbits subjected to the same treatment showed specific damage in the FSH gonadotrophs which was similar to that observed in castrated animals. These observations suggest that the effects obtained by immunization were a consequence of hormonal neutralization and not of immunological injury. Evidence of significant ovarian damage in these rabbits was provided by the absence of the zona pellucida around ova within growing follicles.

Trujillo-Cenóz \& Sotelo (1959) presented evidence that the amorphous material of the zona pellucida is elaborated in the cytoplasm of the follicular cells and later extruded into the zona layer. They showed that the cytoplasm of the follicular cells surrounding the oocyte shows extensive zones occupied by a substance that strikingly resembles the amorphous material. Later, a substance containing polysaccharides (Braden, 1952) appears between the plasma membrane of the oocyte and the granulosa cells, and this material eventually constitutes the zona pellucida. The zona pellucida is PAS-positive under normal conditions due to its high concentrations of sulphated acid mucopolysaccharides (Braden, 1952; Deane, 1952; Konecky, 1959; Chiquoine, $1959,1960)$. In the anti-FSH immunized rabbits, the multibranched cytoplasmic projections of the follicular cells contained dense material which did not appear to be extruded.

The LH contaminant of the FSH used for production of antibodies could not be responsible for this damage since another group of rabbits actively immunized with anti-LH serum had ova with normal zonae pellucidae.

It is not known if the synthesis of the zona pellucida depends upon a direct FSH action on granulosa cells or if it is mediated through the influence of oestrogens.

The authors are indebted to Miss M. Morteyrú and to Miss A. Paczy for their technical assistance. We are grateful to the Endocrinology Section, N.I.H., for ovine FSH. This investigation was supported by grants from The Population Council, New York, to Dr Monastirsky and Dr Elsa Schuchner. 


\section{REFERENCES}

Boyden, S. V. (1951) The adsorption of proteins on erythrocytes treated with tannic acid and subsequent hemagglutination by antiprotein sera. 7. exp. Med. 93, 107.

Braden, A. W. H. (1952) Properties of the membranes of the rat and rabbit eggs. Aust. F. sci. Res. 5, 460.

Casida, L., Meyer, R. K., MaShan, W. H. \& Wisnicky, W. (1943) Effects of pituitary gonadotropins on the ovaries and the induction of superfecundity in cattle. Am. F. vet. Res. 4, 76.

Chiquorne, A. D. (1959) Electron microscopic observations on the developmental cytology of the mammalian ovum. Anat. Rec. 133, 258.

Chrquorne, A. D. (1960) The development of the zona pellucida of the mammalian ovum. Am. $\mathcal{J}$. Anat. 106, 149.

Deane, H. W. (1952) Histochemical observations on the ovary and oviduct of the albino rat during the estrous cycle. Am. F. Anat. 91, 363.

Greep, R. O. (1961) Physiology of the anterior hypophysis in relation to reproduction. In Sex and Internal Secretions, Vol. I, p. 240. Ed. W. C. Young. Williams \& Wilkins, Baltimore.

Konecky, M. (1959) Etude histochimique de la zone pellucide des ovules de chatte. C. r. Séanc. Soc. Biol. 153, 893.

Monastirsky, R., Laurence, K. A. \& Tovar, E. (1971) The effects of gonadotropin immunization of prepubertal rabbits on gonadal development. Fert. Steril. 22, 318.

Schuchner, E. \& Monastirsky, R. (1973) Neutralization of endogenous luteinizing hormone by antibodies in prepubertal female rats. Fert. Steril. 24, 107.

Schwartz, N. \& ELY, C. (1970) Comparison of effects of hypophysectomy, antiserum to ovine LH, and ovariectomy on estrogen secretion during the rat estrous cycle. Endocrinology, 86, 1420.

Segal, S. J., Laurence, M., Perlbachs, M. \& Hakim, S. (1962) Immunologic analysis of sheep pituitary gonadotropins. Gen. $\mathbb{E}$ compar. Endocr., Suppl. 1, 12.

Simpson, M. E. \& VAN WAgenen, G. (1953) Response of the ovary of the monkey (Macaca mulatta) to the administration of the pituitary follicle stimulating hormone (FSH). Anat. Rec. 115, 370.

TalaAt, M. \& LAURENCE, K. (1969) Effects of active immunization with ovine FSH on the reproductive capacity of female rats and rabbits. Endocrinology, 84, 185.

Trujillo-Cenóz, O. \& Sotrlo, J. R. (1959) Relationships of the ovular surface with follicle cells and origin of the zona pellucida in rabbit oocytes. F. biophys. biochem. Cytol. 5, 347. 